Chu, Clara. "Literacy Practices of Linguistic Minorities: Socio-Linguistic Issues and Implications for Literacy

Services," Library Quarterly, 69(3): 339-359, July 1999.

Made available courtesy of University of Chicago Press.

\title{
LITERACY PRACTICES OF LINGUISTIC MINORITIES: SOCIOLINGUISTIC ISSUES AND IMPLICATIONS FOR LITERACY SERVICES ${ }^{1}$
}

\begin{abstract}
Clara M. $\mathrm{Chu}^{2}$
Literacy, as it applies to linguistic minorities, is examined as a discourse of power in this theoretical article. Literacy needs to be redefined in order for librarians to be able to provide people whose languages are not the dominant or official ones in society with appropriate literacy services. This redefinition recognizes the politics of language and literacy, challenges the mainstream (dominant culture) concept of literacy, and includes (1) expanding the definition of literacy that takes into account the language and cultural knowledge of linguistic minorities, (2) examining the nature of literacy and literacy practices of linguistic minorities from a social perspective, and (3) understanding how the literacy of linguistic minorities is measured. By understanding these critical issues of adult literacy in linguistic minority communities, librarians can implement the proposed strategic directions for delivering appropriate literacy services to linguistic minorities.
\end{abstract}

\section{Introduction}

Public discourse on literacy is a discourse of power. As Henry Giroux, a leading scholar in critical pedagogy and critical studies, notes, "In the United States [and other countries], the language of literacy is almost exclusively linked to popular forms of liberal and right wing discourse that reduce it to either a functional perspective tied to narrowly conceived economic interests or to an ideology designed to initiate the poor, the underprivileged, and minorities into the logic of a unitary, dominant cultural tradition" [1, pp. 2-3]. Likewise, the tenet of liter-

1. Based on a paper presented at the Conference of the International Federation of Library Associations and Institutions, August 16-21, 1998, Amsterdam, The Netherlands.

2. Assistant professor, University of California, Los Angeles, Department of Information Studies, 210 GSE\&IS Building, Box 951520, 300 Charles E. Young Drive North, Los Angeles, California 90095-1520; Telephone 310-206-9368; Fax 310-206-4460; E-mail cchu@ ucla.edu.

[Library Quarterly, vol. 69, no. 3, pp. 339-359]

(c) 1999 by The University of Chicago. All rights reserved.

0024-2519/99/6903-0003\$02.00 
acy services in libraries for linguistic minority populations employs similar language. ${ }^{3}$ This functional approach is associated with the acquisition of a set of technical skills, equipping individuals for better jobs and adoption of the dominant culture and language. Implicit in such an approach is that economic prosperity and cultural and linguistic assimilation are a public and desired good and that equal access to economic opportunities and social circles indeed exists. On the contrary, the reality for linguistic and other minorities is rather sinister: they have encountered a racism of exclusion, tokenism, or segregation, and their cultural, religious, and social freedoms have been compromised. (For historical and contemporary treatises of race in the United States see, for example [3-7]). This conceptualization of literacy or the "ideological" model of literacy [8] is elitist, as it defines literacy from the outside or dominant culture (us defining them) and categorizes people into "haves" and "have-nots" [9]. Furthermore, it recognizes neither an individual's literacy in nondominant languages nor differences in literacy levels when engaged in different social circumstances; for example, a doctor is typically less literate at a mathematics conference than at a medical one.

One social circumstance is the interaction with a library, librarian, or information system. A library or an information system presents literacy challenges in its own right [9]. People, such as immigrants, who may not be familiar with what libraries are and how information is organized within them will have difficulties gaining access to them. Mike Baynham [9, pp. 120-21, 126] illustrates this by using the following passage from the novel Kes: $A$ Kestrel for a Knave by Barry Hines [10]:

"Got any books on hawks, missis?"

The girl behind the counter looked up from sorting coloured tickets in a tray.

"Hawks?"

3. Linguistic minorities are people whose languages are not the dominant or official ones in society. Based on the 1990 U.S. Census data on languages other than English spoken at home, more than half ( 54 percent or 17.3 million) of the 31.8 million U.S. residents who spoke a language other than English at home reported they spoke Spanish [2, p. 1]. Spanish was spoken nine times more frequently at home than French (1.9 million), the secondmost frequently spoken non-English language in the home. This was followed by German (1.5 million speakers), Chinese (1.3 million speakers), and Italian (1.3 million speakers). The 1990 Census reflected old and new immigration, respectively, with a decline in the number of speakers of European languages since the last census and an increase in the number of speakers of Spanish, and Asian and Pacific Island languages. Speakers of Asian or Pacific Island languages (for example, Chinese, Japanese, Vietnamese, Hindi, Korean, Tagalog, and other languages) totaled 4.5 million. 
"I want a book on falconry."

"I'm not sure, you'd better try ornithology."

"What's that?"

"Under zoology."

She leaned over the desk and pointed down a corridor of shelves, then stopped and looked Billy over.

"Are you a member?"

"What do you mean, a member?"

"A member of the library."

Billy pressed a finger into the ink pad on the desk and inspected the purple graining on the tip. all."

"I don't know owt about that. I just want to lend a book on falconry, that's

"You can't borrow books unless you're a member."

"I only want one."

"Have you filled one of these forms in?"

She licked a forefinger and flicked a blue form up on her thumb. Billy shook his head.

"Well you're not a member then. Do you live in the Borough?"

"What do you mean?"

"The Borough, the City."

"No, I live out on Valley Estate."

"Well that's in the Borough, isn't it?"

A man approached and plonked two books on the counter. The girl attended to him immediately. Open. Stamp. Open. Stamp. She slotted the cards into his tickets and filed them in a tray. The man pulled his books to the edge of the counter, caught them as they overbalanced, then shouldered his way through the swinging doors.

"Can I get a book now, then?"

"You'll have to take one of these forms home first for your father to sign."

She handed Billy a form across the counter. He took it and looked down at the dotted lines and blank boxes.

"My dad's away."

"You'll have to wait until he comes home then."

"I don't mean away like that. I mean he's left home."

"Oh, I see . . . Well in that case, your mother'll have to sign it."

"She's at work."

"She can sign it when she comes home, can't she?"

"I know, but she'll not be home 'til tea time, and it's Sunday tomorrow."

"There's no rush, is there?"

"I don't want to wait that long. I want a book today."

"You'll just have to wait, won't you?"

“Look, just let me go an' see'f you've got one, an' if you have I'll sit down at one o'them tables an' read it."

"You can't, you're not a member."

"Nobody'll know."

"It's against the rules."

"Go on. I'll bring you this paper back on Monday then."

"No! Now go on home and get that form signed."

She turned around and entered a little glass office.

"I say." 
Billy beckoned her out.

"Now what?"

"Where's there a bookshop?"

"Well, there's Priors up the Arcade. That's the best one."

"O ye! I know."

[in the bookstore]

He started in one corner, and, working from the top shelf, down, up, down, moved along the sections, scanning the categories, which were printed on white cards and stuck on the edges of the shelves: CRAFTS ... DICTIONARIES . . . DEVOTIONAL . . . FICTION . . . GARDENING . . . HISTORY . . . MOTORING . . . NATURE-ANIMALS, one shelf, two shelves. BIRDS, birds, birds. A Falconer's Handbook.

The librarian in the above scene acts as a gatekeeper and assumes that Billy, a working-class teenager who is fascinated by kestrel hawks, is an informed library user. Billy's difficulties emanate from his unfamiliarity with the library as discourse and the library as institution [9]. His difficulties correspond to those experienced by linguistic minorities in mainstream society when they are dealing with an unfamiliar linguistic or institutional discourse. First, Billy's vocabulary for describing his subject of interest ("hawk," then the more technical term "falconry" when the librarian questions the initial word) does not match the system's controlled vocabulary, and he is oblivious to the library's organization system that classifies the topic within ornithology, a subclass of zoology. Second, Billy is barred from using the library because of his unfamiliarity with the library as an institution; not only does he not have membership, the process to obtain it is bureaucratic. In contrast, the scene describing Billy's experience at the bookshop highlights his ability to maneuver the bookshop's discourse, that is, its organization and terminology use.

In order to engage linguistic minorities in developing their literacy skills, they cannot continue to be disenfranchised either in libraries or in the wider society, and they need to be involved in defining, developing, and using their own literacy. Literacy, as it applies to linguistic minorities, needs to be understood as a discourse of power and must be redefined in order for librarians to be able to provide them with appropriate literacy services. This redefinition recognizes the politics of language and literacy, challenges the mainstream (dominant culture) concept of literacy, and includes (1) expanding the definition of literacy that takes into account the language and cultural knowledge of linguistic minorities, (2) examining the socially contextualized nature of literacy and literacy practices of linguistic minorities, and (3) understanding how the literacy of linguistic minorities is measured. By understanding these critical issues of adult literacy in linguistic minority communities, librarians can implement the proposed stra- 
tegic directions for delivering appropriate literacy services to linguistic minorities.

\section{Definitions of Literacy}

The literature on literacy reveals that its conceptualization is social in nature. It shows that literacy has had various definitions during different historical periods and that the extent to which one is literate is different depending on the situation or social context. Anabel Powell Newman and Caroline Beverstock traced changes in the definitions of literacy, which have included the ability to sign one's own name, the ability to read and write, the number of years of formal schooling, and attainment of fourth-grade-level functional literacy [11]. While these definitions emphasized the acquisition of technical skills, other literacy experts have drawn attention to literacy as situationally or socially defined. "If anything is clear from looking at the large body of literature on literacy, it is that the very idea of literacy has changed, and continues to change. Increasingly, literacy is being seen as a social phenomenon, as opposed to an isolated process of decoding/encoding text. Literacy research is beginning to take into account social context and social change, and to pay attention to the relationship between literacy and gender" [12, p. 8].

Basic or technical definitions of literacy are concerned with the acquisition of literacy skills, that is, reading, writing, and speaking a language, and expanded definitions make reference to the benefits of literacy. Robert Disch describes the benefits of literacy as twofold: utilitarian, and aesthetic and spiritual [13]. Utilitarian benefits include economic prosperity, social advancement, and intellectual growth. Anthropologists Sylvia Scribner and Michael Cole define literacy in a basic way as "a set of socially organized practices which make use of a symbol system and a technology for producing and disseminating it" [14, p. 236]. This definition, used to research learning and uses of literacy in West African Vai culture, refers to language as a symbol system and is inclusive of both oral and written languages. Such a definition does not exclude oral literacy, such as found in the Hmong and some Native American cultures. The Scribner and Cole definition also describes literacy as a set of socially organized practices, recognizing societal control and influence or group consensus in the setting of literacy behavior and standards.

An example of an expanded definition is found in the National Literacy Act of 1991 of the United States. It defines literacy as "an individual's ability to read, write and speak in English and compute and solve 
problems at levels of proficiency necessary to function on the job and in society, to achieve one's goals, and one's knowledge and potential." For a multicultural nation, such as the United States, this definition is exclusionist because it refers to literacy in only English, the official language.

Another aspect of literacy not included in the above expanded definition is the ability to analyze and critically evaluate information, that is, "information literacy." It is necessary because it is critical for individuals to recognize the context, the quality, and hidden agenda of the information being consumed. Furthermore, as we encounter an increasingly information- and technology-intensive world, one requires the ability to read and write using multimedia, preferably in English, and to critically evaluate texts. The emphasis on the English language is due to the Anglo-American bias of multimedia, such as the Internet $[15,16]$. This "new literacy" [17] is considered to be essential to the success of our youth, especially as we enter the next millennium. Similar competencies are expressed in the new Information Literacy Standards for Student Learning developed by the American Association of School Librarians and the Association for Communications and Technology [18]. Their nine standards are clustered in three areas: information literacy, independent learning, and social responsibility. A significant aspect of these standards is the view that information consumption and application are interdependent, which is demonstrated by linking information literacy to self-development and societal participation.

The definitions of literacy examined thus far are representative of the diverse views that exist regarding the concept of literacy and show that "literacy" can mean something different depending on time, place, and situation. Thus, libraries have been influenced by the way literacy has been defined by policy makers over time-definitions that have tended to emphasize functional skills. In order for librarians to provide appropriate literacy services to linguistic minorities, they need to expand their concept of literacy to take into account the language and cultural knowledge of linguistic minorities. The notions of multiple literacies and emancipatory literacy, to be discussed later, are such concepts.

\section{Socially Contextualized Nature of Literacy}

The new views of literacy "put the insights and perspectives of literacy learners and users at the centre of research about literacy," document "the variety of communicative styles and cultural values that people 
bring to literacy," and look "at literacy in its broader social context" $[19$, p. 3]. It is these particular people-centered and social views that illuminate for literacy workers the nature of literacy in linguistic minority communities. To begin to explore the socially contextualized nature of literacy and how it adds to the complexity of defining literacy in linguistic minority communities, I offer the following two contrasting examples:

My mother, Josefina, was born in a village in Guangdong, China, in 1928, during a time when most girls did not have the privilege to learn to read and write. However, my mother persevered and learned the Chinese language. She married and in 1958 moved to Peru, where my sisters and I were born. Our family lived within the company compound where my mother had little contact with the outside world except for family outings and weekly trips to the public market. She learned the language of the market and to negotiate with vendors. She relied on my father or relatives for other needed interactions with Peruvian society, and in their absence, mishaps occurred, such as a dentist removing the wrong tooth. In 1970, our family moved to Vancouver, Canada. Here, she found a large concentrated Chinese community where she could obtain most services and mass media in Chinese, and encountered clearly marked prices that made shopping easy, and well-mapped out and labeled transportation routes that facilitated local travel. My mother felt at ease and visited friends and conducted personal business independently although she knew less English than Spanish. She only learned a few English greetings, and amazingly, obtained her Canadian citizenship by passing an oral examination in English after intensive study. In Canada my mother relied on her children to communicate with the English-speaking world. She did not use libraries even though she knew the value of libraries for her children and was aware that some had Chinese language materials. She stayed at home carrying out the duties of a homemaker and only in the last years of her life did she join any social groups: a Presbyterian Church and a neighborhood Tai Chi group.

Mrs. Wong (fictitious name) was in her late 60 s when I met her and unlike my mother she was abuzz with activities, more of a social butterfly than her own children. She had immigrated to Canada in her 50s and already knew English because she was raised in an upper middle-class family in Hong Kong, had received private schooling, graduated from high school, and was wellread. In Canada, she attended advanced ESL [English as a Second Language] classes to improve her English, took arts and crafts classes at a community recreation center, was an active library user and community volunteer, swam regularly at a public pool, and completed translation jobs on her home computer.

These stories begin to demonstrate not only the various types of literacies that can exist in linguistic minority or immigrant communities but also the differences in social life and networks, educational background and pursuit of education, and family responsibilities. They reveal that the extent to which a person is literate in their heritage or other languages can depend on their culture, social role, education, economic status, and length of residence in their native or adoptive 
country. For example, the 1992 National Adult Literacy Study (NALS) shows that those with higher educational attainment had higher levels of English literacy on all scales [20]. These stories also demonstrate differences in the extent of coping, acculturation, and socialization in the dominant culture of their adoptive countries.

If we were to classify my mother using the National Literacy Act of 1991 of the United States (see above), she would be considered illiterate. Despite being able to cope with a limited English or Spanish vocabulary and a help network made up of family and friends, being literate in Chinese, and having succeeded in her role as mother and homemaker, my mother would be considered illiterate in both her adoptive countries except in the ethnic Chinese communities. This view of literacy is shortsighted in the context of delivering literacy services because it does not build on existing literacies and it views linguistic minorities as having nothing to offer to the learning process. Similarly, Baynham is concerned that "if literacy/illiteracy defines and categorizes people, being sorted into the 'have-not' box carries with it the stigma of being defined by a lack. It creates what [Paulo] Freire calls 'a culture of silence.' There is no necessary outward sign that someone has difficulties with reading and writing. It is well documented that adults with literacy difficulties develop networks and strategies to cope with their reading and writing demands" [9, pp. 6-7]. Such a culture of silence conceals the literacy needs that exist in linguistic minority communities.

According to Brian Street, the new views of literacy no longer consider literacy as a "have/have-not" dichotomy, but rather as a continuum, and incorporate a broad disciplinary base in understanding literacy:

The field of literacy studies has expanded considerably in recent years and new, more anthropological and cross-cultural frameworks have been developed to replace those of a previous era, in which psychologistic and culturally narrow approaches predominated (as they arguably still do in much educational and development literature). Where, for instance, educationalists and psychologists have focused on discrete elements of reading and writing skills, anthropologists and sociolinguists concentrate on literacies-the social practices and conceptions of reading and writing. The rich cultural variation in these practices and conceptions leads us to rethink what we mean by them and to be wary of assuming a single literacy where we may simply be imposing assumptions derived from our own cultural practice onto other people's literacies. . . Research into 'vernacular' literacies within modern urban settings has begun to show the richness and diversity of literacy practices and meanings despite the pressures for uniformity exerted by the nation state and modern education systems. $[8$, p. 1$]$

\section{Literacy Practices of Linguistic Minorities}

Baynham defines literacy practice as " 'concrete human activity,' involving not just the objective facts of what people do with literacy, but 
also what they make of what they do, how they construct its value, the ideologies that surround it" $[9$, p. 53]. For this article, literacy practices are simply defined as literacy activities viewed in their social and cultural contexts. The two anecdotes provided earlier offer a glimpse of the literacy practices or "vernacular" literacies of linguistic minorities while the following empirical studies offer a window into their literacy world.

In Kathleen Rockhill's study of Hispanic immigrant women in Los Angeles [21], these women, like my mother, did most of the literacy work of the household; engaged others to assist them with English to conduct transactions dealing with social services, public utilities, health care, and schooling of children; acquired sets of English literacy skills for a few situations that occurred on a regular basis; framed learning English in terms of going to school and learning; and viewed their own success in the success of their children. Unlike my mother, these women desired to learn English but were denied by their husbands, who viewed it not as personal growth but a threat to the power relations in the family. Marcia Farr's study of Mexican families in Chicago reported similar findings [22]. Literacy, like other resources, was shared so those more proficient in literacy helped those less proficient and was exchanged for other resources or favors. Literacy was also perceived as "something apart, as something generally linked to formal schooling, as a technology to learn for use in their own lives" [22, p. 103].

Tricia Hartley studied Pakistani Muslim women living in Brierfield, England, a small town of approximately ten thousand inhabitants [23]. Panjabi, which does not have a written form in Pakistan, was spoken among this Pakistani community and Urdu, the national language of Pakistan, was used for written communication. She found that literacy in English or Urdu, like other resources, was made available to family and community; reading and writing was not essential in the everyday lives of the women in the study; oral skills were adequate to conduct their everyday activities; news was read out loud from English or Urdu language newspapers to the family by husbands or other family members; children's English skills were respected, admired, and employed when needed; and aspirations for their children were for them to be literate in both English and Urdu; reading was enjoyed by family members who had the skills although there was frustration about the lack of time to pursue it; and children were encouraged to read by the participating women.

Baynham [9] has found that the social networks in a Moroccan community living in the United Kingdom mirror the traditional social distribution of Moroccan society reported in anthropological studies by Clifford Geertz, Hildred Geertz, and Lawrence Rosen [24] and Daisy Hilse Dwyer [25]. They found differences between women's social net- 
works, which focused inward or were tied to the home, and men's social networks, which focused outward and were more communal. Women's networks were co-extensive with the family and immediate neighborhood, and men's networks extended out into the market, coffee shops, mosque, school, workplaces, and the street. Baynham also found that an interpreter strategy of using formal and informal mediators of literacy is practiced [9]. The use of formal mediators of literacy follows the practice in some countries of using a public scribe, who can be found in the marketplace and for a fee will read, write, or type a document. Informal mediators include family members, neighbors, and friends.

The use of an interpreter strategy has been explored in library and information science. Cheryl Metoyer-Duran has identified gatekeepers in ethnolinguistic communities as those information providers who move between two ethnolinguistic communities [26]. They are formal gatekeepers if they hold a position to assist linguistic minorities and informal gatekeepers if such assistance is performed on a voluntary basis. I have studied the role of bilingual children who serve as cultural, linguistic, and information mediators [27] for their immigrant and linguistic minority parents, relatives, or friends. Both adult ethnolinguistic gatekeepers and immigrant children mediators serve as important sources of information and interpretation for linguistic minorities who are then able to gain access to information only found in the dominant language and mainstream institutions and to communicate with English monolingual speakers in order to acquire goods and services not available in ethnic communities.

The use of traditional social networks has been transplanted by the Hmong to the United States. The patrilineal clan system, made up of twenty clans, that organizes Hmong society continues to integrate the Hmong community and culture in Philadelphia [28]. This kinship relationship is so strong and embedded into the social order that a clan member will find assistance from a fellow clan member within or outside their local community. However, in the United States this kinship system is not always recognized by social service institutions, which expect the Hmong to assist each other across clan kinship. Some Hmong who have few family or clan ties may look outward into American society rather than seek assistance from a Hmong of another clan.

In a study of adults with limited literacy skills in Appalachia and immigrants in California, Juliet Merrifield, Mary Beth Bingman, David Hemphill, and Kathleen P. Bennett de Marrais identified four main types of literacy strategies used in their daily lives $[29$, p. 186]:

1. Other-oriented strategies, including using regular "readers," asking others for help or information on an ad hoc basis, using other oral information sources, and observing others

2. Self-reliance strategies, including guessing, extensive use of memory, learn- 
ing routines, and selective use of text (including native language text when people are literate in their native language but not in English)

3. Avoidance of difficult or potentially difficult situations

4. Substitution of technology for literacy, such as television, VCRs, computers, and tape recorders

In order to assist linguistic minority communities to develop literacy in their heritage or dominant languages, the social backdrop in which literacy instruction would be delivered needs to be understood. This includes the extent of preparedness for literacy instruction and the competing factors barring participation in literacy programs. My personal observations and review of research reveal the following sociolinguistic factors that literacy workers need to consider:

1. Conventional cultural roles that dictate an individual's responsibility and literacy acquisition may exist. For example, my mother, raised in the Chinese culture, accepted the fact that she was not an educated woman and did not need to be; she felt fortunate that she overcame the odds and learned to read and write Chinese; she had numeracy skills; she saw her primary role as that of mother and housewife; and her success was found in the success of her children. In the case of Hispanic women in Los Angeles, their husbands prohibited them from learning English [21]. Understanding of cultural roles may indicate a reluctance to participate in literacy programs and one's social isolation from the larger community.

2. Literacy level in the heritage language needs to be assessed and, as appropriate, used to build literacy skills in the dominant language. It may indicate the extent of one's readiness and willingness to participate in literacy programs and social isolation from the larger community.

3. Educational attainment can reveal one's familiarity, or lack thereof, with educational institutions and practices, thus suggesting one's desire or readiness to participate in literacy programs.

4. Existence of a local ethnic community, services, and media may signify exclusive use of such services, isolation from the dominant culture and society, and less of an imperative to acquire literacy in the dominant language.

5. Social isolation and networks need to be examined to identify the diversity of social circumstances. Individuals may be socially isolated both from their own linguistic community and the larger community, or they may have an extensive social life in one or more communities. Social isolation may indicate less interest in participating in activities outside of the home and special outreach efforts would be needed.

6 . The literacy of coping as practiced by my mother and other immigrants allow them to conduct their daily activities; therefore, dominant language acquisition may appear unnecessary. Examples of strategies 
for coping and transition across diverse "discourse communities" or sociolinguistic contexts include the use of formal and informal networks; the use of heritage language when there are similarities (for example, English and Spanish); learning a limited set of literacy skills for routine activities, such as answering the telephone; and use of ethnic services and media.

7. Because work and household duties are priorities, it may be impossible for an immigrant to fit literacy classes into a busy work schedule; the need to take care of family responsibilities first, especially for women, may take precedence over improving one's literacy.

Linguistic minorities are extraordinary at coping without dominant language literacy, especially if there is an ethnic community. The conditions in which linguistic minorities find themselves may be self- or institutionally imposed and reflect both their readiness to embark on a path of literacy and the challenge for librarians and other literacy workers. For immigrant women, their literacy practices can position them in the home and constitute their identities in familial terms [30].

\section{Measuring Literacy in Linguistic Minority Communities}

Data on the literacy of linguistic minorities are often unavailable or inaccurate. Such flaws encountered in the data are often due to problems in data collection. There are three common methods of measuring literacy: self-reported information, surrogate indicators, and direct measures [31]. Self-reported data are considered unreliable because they are subjective and perceptual or based on reported levels of schooling, which have the associated problems of surrogate indicators. Surrogate indicators, such as grade-level achievement, may not be reliable indicators because literacy can also be acquired in the home, community, and workplace, or if unused, it does not reflect mastery of the respective grade level, and different regional or national grade standards may not be comparable. It is best to rely on actual assessments, but they are typically biased toward national language achievement, that is, the encoding/decoding of the dominant language system.

The NALS conducted in 1992 found that white adults scored significantly higher than every other racial and ethnic group on the three literacy scales used: prose literacy, document literacy, and quantitative literacy. The limitation of the NALS was that it was "a survey of literacy in the English language-not literacy in any universal sense of the word. Thus, the results do not capture the literacy resources and abilities that some respondents possess in languages other than English" [20, p. 13]. Although international literacy data now exist on twelve 
countries (Canada, Germany, the Netherlands, Poland, Sweden, Switzerland, the United States, Australia, Belgium [Flanders], Ireland, New Zealand, and the United Kingdom) that participated in the International Adult Literacy Survey (IALS), again the literacy standard is that of the dominant language of the respective country. The IALS is the first multicountry and multilanguage assessment on adult literacy allowing comparison across cultures and languages [32].

The limitation of most national literacy assessments is fourfold [33]. First, they measure national/dominant language literacy and do not recognize the other literacies people possess, such as heritage language literacy, sign language, and braille or literacies of the home, work, or community. Second, there is an overemphasis on oral/spoken language ability that can lead to an overcount because it is only a partial test of one's ability to read, write, and speak in the dominant language. Third, studies often undercount linguistic minority groups due to sampling biases, and for this reason, such groups were oversampled in the NALS to address this potential problem. Fourth, the identification used to label those in the sample is ambiguous as to race, ethnicity, or language can confound the data. For example, the term "Hispanic" may refer to any one of the above three elements and would need to be clarified to accurately understand the findings and their implications for educational policy [34]. In other words, the term is open to various interpretations, such as a person could be Hispanic in terms of ethnicity or race but may not speak Spanish, a person may speak Spanish but may not be Hispanic in terms of race and ethnicity, or a person could be Hispanic in terms of race, ethnicity, and language. Each category represents differences in English and/or Spanish literacy that need to be clarified and operationalized for those conducting, participating, and reading about the survey.

An additional fifth problem with national assessments is the elitist/ hegemonic approach used to define literacy in research. For example, in two studies of limited English literacy categories using pejorative terminology were used. The Survival Literacy Study [35] used three categories: low survival, questionable survival, and marginal survival, and in the Adult Performance Level study [36] the three categories used were functionally incompetent, marginally functional, and functionally proficient.

Based on national assessments, the level of functional literacy among racial and ethnic minorities is thought to be low. The 1990 Census reports that 31.8 million adults in the United States or 14 percent of the population over five years old stated they spoke a language other than English. Of those, 6.7 million (21 percent) indicated they spoke English "not well" or "not at all" [2]. 
The National Adult Literacy Survey indicates that the number of speakers of other languages who have difficulties with English literacy is significantly higher than the Census figures. While $33 \%$ of legal immigrants come to the states with postsecondary education and training and advanced professional degrees, just as many have had only a few years of schooling in their home countries. These latter adults have not had the opportunity to develop strong literacy skills in their native languages.

Still others come from cultures where there are different cultural uses of literacy than in the United States. In these cultures, specific classes or groups, such as business people or religious leaders, may have strong literacy skills, while others, such as farmers and adult women, have no experience with reading or writing at all. Recent immigrants include the Hmong of Cambodia ${ }^{4}$ who do not rely on a written language at all.

Although many of these adults have acquired conversational skills in English, they often lack the reading and writing skills necessary for access to training, job mobility, or success in regular ESL classes. [37]

\section{Strategic Directions for Delivering Appropriate Literacy Services to Linguistic Minorities}

Historically, libraries in the United States have provided services to support the literacy instruction of immigrants. The tradition goes back to the turn of the century when adult literacy education was made available to immigrants to learn the language of their new country [38]. These services, provided in libraries and other institutions, were part of an "Americanization" campaign, mainly targeting European immigrants. Dating back to 1894 , there was discussion about the public library's role in promoting good citizenship. Early public library efforts included the provision of some foreign language books to draw in immigrants [39] and the establishment of subbranch libraries in poor districts to maximize accessibility [40]. Subsequent debates continued about the methods that would satisfactorily foster good citizenship. They ranged from hiring library assistants who spoke the patrons' native language, providing English-only materials, marketing the library in various languages, providing programs and easy reading materials on American citizenship, and designing customized programming for patrons of different nationalities.

In contrast to the educational opportunities available to European immigrants, black slaves in the United States were denied education and literacy $[11$, p. 24], and until the early twentieth century educational

4. The majority of Hmong immigrants are from Laos rather than Cambodia. See Carl L. Bankston III, "Hmong Americans," in Gale Encyclopedia of Multicultural America, edited by Judy Galens, Anna J. Sheets, and Robyn V. Young (New York: Gale Research, Inc., 1995), vol. 1, pp. 670-81. 
opportunities and library services to blacks were poor [40]. "We can see in immigrant and African American experience the results of professional action that worked toward unity and disunity, respectively, as librarians set policies to encourage basic educational opportunities for immigrants and discourage the availability of such opportunities for Blacks" [40, p. 97]. Although literacy was not explicitly stated, restriction or inaccessibility to reading materials in libraries created literacy barriers for African Americans.

More recently, libraries have had several incentives to renew their literacy efforts. For one, Unesco designated 1990 as the International Year of Literacy. Another was President Clinton's America Reads Challenge, a component of his 1996 reelection campaign, in which he requested legislation to ensure that by the year 2000 eight-year-old children in America have the ability to read. This challenge prompted an issue of American Libraries (May 1997) featuring several articles on literacy as the library's mission and descriptions of successful programs.

Literacy services, or lack thereof, have been offered on the terms of the dominant society and have emphasized technical skills. Jean Coleman [41] notes that in the 1980s three basic concepts of literacy were often discussed: prevention of illiteracy, functional illiteracy, and aliteracy. Prevention referred to providing literacy in the early school years and to families to prevent intergenerational illiteracy. Functional illiteracy was concerned with the lack of basic literacy skills held by a portion of the population. Aliteracy described those that had the ability to read but did not exercise their skills. At the beginning of this decade, libraries were offering services to address functional illiteracy [41]; however, attention to the needs of linguistic minorities was not expressed or recognized. "In literacy work, we have been slow to realize that the programs and practices we assign to illiterate learners often are at variance with the learners' cultural background and the values that govern their lives" [11, p. 3]. Likewise, Allan Luke calls for a reconceptualization of literacy as a social, communicative practice [42, p. 79]:

Standards and practices for the teaching of literacy change over time, according to cultural, economic and political demands. Hence, current research signals that literacy is not a private and internal, universal and unchanging psychological matter, but rather a social phenomenon that is learned within and through a range of cultural contexts in community, home and school. This challenges the common sense of several generations of teachers and researchers: the belief that literacy teaching should involve the precise imparting of discrete skills, which in turn are best mastered through routines of isolated skill training.

Librarians and other literacy workers need to adopt a definition of 
literacy that values the actual abilities of linguistic minorities and serves as the source from which to develop dominant language literacy. These concerns are captured in the notion of multiple literacies: "We enjoy the richness of multiple literacies-the literacy of our specialized field of endeavor, the jargon of our favorite sport or hobby, the dialect of our hometown or ethnic group" [11, p. viii]. This view of multiple literacies espouses an adaptive approach where "it may be more useful to consider literacy as a continuum and the goals of adult literacy programs to be less those of combating illiteracy and more of expanding literacy" [43, p. 3].

It should be clear now that the broader definition of literacy-that is, "multiple literacies"-proposed here demands the adoption of emancipatory literacy as proposed by the educator Paulo Freire. "Central to Freire's approach to literacy is a dialectical relationship between human beings and the world, on the one hand, and language and transformative agency, on the other. Within this perspective, literacy is not approached as merely a technical skill to be acquired, but as a necessary foundation for cultural action for freedom, a central aspect of what it means to be a self and socially constituted agent" [1, p. 7]. In Freire's view [44], an illiterate is an individual oppressed within a dominant system rather than a person living on the fringe of a society, a marginal man. This view of "marginality" was advanced by Silva Simsova [45], who viewed immigrants as caught between two or more social worlds and considered libraries as one institution to assist immigrants to acculturate in the country of immigration. Although this approach has its own validity, I assume Freire's view of the literacy process as cultural action for freedom. Furthermore, emancipatory literacy includes teaching literacy beginning with one's native language. In his Every Person a Reader report, Stephen D. Krashen [46] cites research showing that it is much easier to learn to read in a language we already understand, and the ability to read transfers across languages, even when the writing systems are different.

From what we have learned about the literacy strategies and social context of linguistic minorities, and their limited interaction with mainstream society, it is not improbable that they may perceive librarians as gatekeepers and representatives of the dominant culture who offer literacy services as a form of assimilation. It is thus essential that the concept of emancipatory literacy, the notion of multiple literacies or of expanding one's literacies, and an understanding of the social context of linguistic minority groups guide the development of appropriate literacy services for linguistic minorities. The following literacy services and activities are recommended to libraries and librarians in order to foster literacy in linguistic minority communities: 
1. Information and learning resources.-These would include literacy materials and information (that is, reference and referral) both for literacy learners and instructors. Materials should be in diverse formats, media, and languages and should incorporate subject content of diverse cultures. Information about the sociocultural background of learners, and effective methods of inter-/cross-cultural teaching and communication should be available for instructors. Theoretical, pedagogical, and curricular materials for literacy instruction for linguistic minority communities should also be available for instructors.

2. Literacy programs.-These programs should do the following:

a) Begin with the participants' native/heritage language(s).

b) Offer introductory to advanced classes to address the diverse needs that may exist and to ensure that the full potential of learners is not limited by the teaching of only short-term, basic skills. "In a recent study by the Lila Wallace Foundation, The Southport Institute found that the ESL delivery system (which includes state and local funded programs, and refugee, welfare and job-training programs in addition to those supported by federal Adult Education Act dollars) is strong in meeting immediate, short-term survival needs but weak [in] helping adults improve their skills to the point where they can take full advantage of the economic and social opportunities of American life" [47, p. 1]. Likewise, "library tutoring programs ... usually provide services to adults at the lowest ability levels, using relatively untrained volunteers for tutors" [48, p. 2].

c) Use content and pedagogical methods that are culturally relevant to the participants. More specifically, Freire wishes "to emphasize that in educating adults, to avoid a rote, mechanical process one must make it possible for them to achieve critical consciousness so that they can teach themselves to read and write. As an active educational method helps a person to become consciously aware of his context and his condition as a human being as Subject, it will become an instrument of choice. At that point he will become politicized" [44, p. 408]. Thus, instruction needs to incorporate participants' own experience and everyday literacy needs.

d) Incorporate into classes as well as offer separately the teaching of information and critical literacy.

e) Remove barriers to participation [see 49]. For example, a family literacy program with a multigenerational focus should provide child care and have families learning and spending time together. Neighborhood locales should be used to hold classes, and 
flexible scheduling should be made available to facilitate program participation and attendance.

3. Collaboration.-Partnering with business and industry, government, media, and educational, penal, social service, community, religious, and other institutions increases literacy efforts and delivery channels and reduces duplication. These partnerships can take on various forms to promote resource sharing and to take advantage of respective expertise and strengths. Libraries may recommend titles; accommodate special use of their materials, such as rotating materials at different sites; provide classroom or meeting space; and offer information and critical literacy instruction. Collaboration is a commitment to the community.

4. Advocacy and awareness.-Literacy should be advanced and fostered at all levels of society. Information literacy (including library use) should be made an objective for all learners. In addition to promoting literacy and literacy services through organizations and the ethnic media, outreach to individuals isolated from the community is critical.

5. Research and education.-Both research and education are needed in order to improve literacy services to linguistic minorities. Studies to find ways to support literacy education by libraries for non-English speakers (including those with learning and other disabilities) are needed. Librarians should be trained in the provision of literacy services; therefore, relevant courses should be offered in the library and information science curriculum. Research in library and information science, education, and other fields should be incorporated into these courses. Lastly, better and diverse types of assessment and testing need to be conducted. "Almost all program output measures are of academic or functional skills, yet most researchers agree that attitudes and beliefs also deserve attention" [48]. Currently, "the primary reasons for literacy testing, from which data are regularly accessed by policymakers, are: (1) national and state population assessments (for example, NALS), (2) individual skill assessments, (3) placement procedures, some of which involve testing, and (4) program evaluation" [50].

\section{Conclusion}

As we enter the new millennium, in order to provide appropriate literacy services to linguistic minorities, librarians need to broaden their definition of literacy, rethink their delivery mechanisms, and embrace emancipatory literacy as an approach to self-determination, self-em- 
powerment, civic involvement, and lifelong learning for linguistic minorities. Drawing on the work of family literacy programs, literacy programs and services in libraries should be designed to foster social justice, whereby linguistic minorities are full participants in the development, implementation, and evaluation of literacy programs [51]. Such an approach assumes the use of culturally relevant pedagogical practices and subject content, values local literacies (individual, cultural, and community), moves beyond literacy development for socioeconomic advancement, and gives voice to linguistic minorities as to their literacy needs.

\section{REFERENCES}

1. Giroux, Henry A. Introduction to Literacy: Reading the Word and the World, by Paulo Freire and Donald Macedo. Westport, Conn.: Bergin \& Garvey, 1987.

2. Bureau of the Census. We Asked . . You Told Us: Language Spoken at Home. Washington, D.C.: U.S. Department of Commerce, Bureau of the Census, February 1994.

3. Davis, Angela Y. Women, Race and Class. 1st Vintage ed. New York: Vintage, 1983.

4. Delgado, Richard, and Stefancic, Jean, eds. Critical White Studies: Looking behind the Mirror. Philadelphia: Temple University Press, 1997.

5. Frankenberg, Ruth, ed. Displacing Whiteness: Essays in Social and Cultural Criticism. Durham, N.C.: Duke University Press, 1997.

6. Lubiano, Wahneema, ed. The House That Race Built. Reprint ed. New York: Vintage, 1998.

7. Takaki, Ronald T. A Different Mirror: A History of Multicultural America. Boston: Little, Brown, 1993.

8. Street, Brian. "Introduction: The New Literacy Studies." In Cross-Cultural Approaches to Literacy, edited by Brian Street, pp. 1-21. Cambridge: Cambridge University Press, 1993.

9. Baynham, Mike. Literacy Practices: Investigating Literacy in Social Context. London: Longman, 1995.

10. Hines, Barry. Kes: A Kestrel for a Knave. London: Michael Joseph, 1974.

11. Newman, Anabel Powell, and Beverstock, Caroline. Adult Literacy: Contexts and Challenges. Newark, Del.: International Reading Association, 1990.

12. Weinstein, Lee, and Lewis, Debra. "Making Connections: Approaches to Adult Literacy." Transition 28 (March 1998): 7-8.

13. Disch, Robert, ed. The Future of Literacy. Englewood Cliffs, N.J.: Prentice-Hall, 1973.

14. Scribner, Sylvia, and Cole, Michael. The Psychology of Literacy. Cambridge, Mass.: Harvard University Press, 1981.

15. "World Library Leaders Gather in NYPL." Library Times International 13 (July 1996): 1-2.

16. World Wide Web Consortium. "Internationalization/Localization: Non-Western Character Sets, Languages, and Writing Systems" [1997]. Internet address: http:/ / www.w3.org/ International/ (last visited January 20, 1999).

17. Hill, Maggie. "The New Literacy: Beyond the Three Rs." Electronic Learning 12 (September 1992): $28-34$.

18. American Association of School Librarians and Association for Educational Communications and Technology. Information Power: Building Partnerships for Learning. Chicago: Amer- 
ican Library Association and Association for Educational Communications and Technology, 1998.

19. Hamilton, Mary. "Introduction: Signposts." In Worlds of Literacy, edited by Mary Hamilton, David Barton, and Roz Ivanic, pp. 1-13. Clevedon, England: Multilingual Matters, and Toronto: Ontario Institute for Studies in Education, 1994.

20. Kirsch, Irwin S.; Jungeblut, Ann; Jenkins, Lynn; and Kolstad, Andrew. Adult Literacy in America: A First Look at the Results of the National Adult Literacy Survey. Washington, D.C.: U.S. Department of Education, Office of Educational Research and Improvement, September 1993.

21. Rockhill, Kathleen. "Gender, Language and the Politics of Literacy." In Cross-Cultural Approaches to Literacy, edited by Brian Street, pp. 156-75. Cambridge: Cambridge University Press, 1993.

22. Farr, Marcia. "Biliteracy in the Home: Practices among Mexicano Families in Chicago." In Adult Biliteracy in the United States, edited by David Spener, pp. 89-110. McHenry, Ill.: Center for Applied Linguistics and Delta Systems Company, 1994.

23. Hartley, Tricia. "Generations of Literacy among Women in a Bilingual Community." In Worlds of Literacy, edited by Mary Hamilton, David Barton, and Roz Ivanic, pp. 29-40. Clevedon, England: Multilingual Matters, and Toronto: Ontario Institute for Studies in Education, 1994.

24. Geertz, Clifford; Geertz, Hildred; and Rosen, Lawrence. Meaning and Order in Moroccan Society: Three Essays on Cultural Analysis. Cambridge: Cambridge University Press, 1979.

25. Dwyer, Daisy Hilse. Images and Self-Images: Male and Female in Morocco. New York: Columbia University Press, 1978.

26. Metoyer-Duran, Cheryl. Gatekeepers in Ethnolinguistic Communities. Norwood, N.J.: Ablex, 1993.

27. Chu, Clara M. "Immigrant Children as Mediators and the Role of Information." Paper presented at the program "American Made, Not Born: Working with New American Young Adults," Young Adult Library Services Association, American Library Association Conference, June 22-28, 1995, Chicago.

28. Weinstein-Shr, Gail. "Literacy and Social Process: A Community in Transition." In CrossCultural Approaches to Literacy, edited by Brian Street, pp. 272-93. Cambridge: Cambridge University Press, 1993.

29. Merrifield, Juliet; Bingman, Mary Beth; Hemphill, David; and de Marrais, Kathleen P. Bennett. Life at the Margins: Literacy, Language, and Technology in Everyday Life. New York: Teachers College Press, 1997.

30. Street, Brian V. "Struggles over the Meaning(s) of Literacy." In Worlds of Literacy, edited by Mary Hamilton, David Barton, and Roz Ivanic, pp. 15-20. Clevedon, England: Multilingual Matters, and Toronto: Ontario Institute for Studies in Education, 1994.

31. Wiley, Terrence G. "Estimating Literacy in the Multilingual United States: Issues and Concerns." ERIC Digest EDO-LE-94-04, September 1994. Internet address: http:// www.cal.org/cal/html/pubs/ncledig/wiley.htm (last visited January 20, 1999).

32. Human Resources Development Canada. "International Adult Literacy Survey" [1997]. Internet address: http://www.nald.ca/nls/ials/introduc.htm (last visited January 20, 1999).

33. Macías, Reynaldo F. "Inheriting Sins While Seeking Absolution: Language Diversity and National Statistical Data Sets." In Adult Biliteracy in the United States, edited by David Spener, pp. 15-45. McHenry, Ill.: Center for Applied Linguistics and Delta Systems Company, 1994.

34. Macias, Reynaldo F. "Language and Ethnic Classification of Language Minorities: Chicano and Latino Students in the 1990's." Hispanic Journal of Behavioral Sciences 15 (1993): 230-57. 
35. Harris, L., and Associates. Survival Literacy Study. Washington, D.C.: Government Printing Office, 1970.

36. Northcutt, Norvell. Adult Functional Competency: A Summary of the Adult Performance Level Project. Austin: University of Texas, Division of Extension, March 1975.

37. National Institute for Literacy. "What Kind of Adult Literacy Policy Will Help All Adults Develop the English Language and Literacy Skills They Need to Participate Fully in American Life?" [ca. 1994]. Internet address: http://www.nald.ca/fulltext/report4/rep3640/rep40-02.htm (last visited January 20, 1999).

38. Adult Literacy: The Key to Lifelong Learning. Albany: State University of New York, New York State Education Department, Office of Continuing Education, 1992.

39. Marcum, Deanna B., and Stone, Elizabeth W. "Literacy: The Library Legacy." American Libraries 22 (March 1991): 202-5.

40. MacCann, Donnarae. "Libraries for Immigrants and 'Minorities': A Study of Contrasts." In Social Responsibility in Librarianship: Essays on Equality, edited by Donnarae MacCann, pp. 97-116. Jefferson, N.C.: McFarland, 1989.

41. Coleman, Jean Ellen. "The Social Responsibilities of Librarians toward Literacy Education." In Social Responsibility in Librarianship: Essays on Equality, edited by Donnarae MacCann, pp. 31-41. Jefferson, N.C.: McFarland, 1989.

42. Luke, Allan. "The Non-neutrality of Literacy Instruction: A Critical Introduction." Australian Journal of Reading 11 (June 1988): 79-83.

43. Crandall, JoAnn, and Imel, Susan. "Issues in Adult Literacy Education." ERIC Review 1 (April 1991): 2-5.

44. Freire, Paulo. "The Adult Literacy Process as Cultural Action for Freedom and Education and Conscientização." In Perspectives on Literacy, edited by Eugene R. Kintgen, Barry M. Kroll, and Mike Rose, pp. 398-409. Carbondale: Southern Illinois University Press, 1988.

45. Simsova, S[ilva]. "The Marginal Man." Journal of Librarianship 6 (January 1974): 46-53.

46. Krashen, Stephen D. Every Person a Reader: An Alternative to the California Task Force Report on Reading. Culver City, Calif.: Language Education Associates, 1996.

47. National Institute for Literacy. "What Kind of Adult Literacy Policy Will Help All Adults Develop the English Language and Literacy Skills They Need to Participate Fully in American Life?" [ca. 1994]. Internet address: http:/ / www.nald.ca/fulltext/report4/rep3640/rep40-01.htm (last visited January 20, 1999).

48. Venezky, Richard L. "Matching Literacy Testing with Social Policy: What Are the Alternatives?" [1994]. Internet address: http://www.nald.ca/fulltext/report4/rep36-40/ rep39-02.htm (last visited January 20, 1999).

49. National Institute for Literacy. "What Kind of Adult Literacy Policy Will Help All Adults Develop the English Language and Literacy Skills They Need to Participate Fully in American Life?" [ca. 1994]. Internet address: http://www.nald.ca/fulltext/report4/rep3640/rep40-03.htm (last visited January 20, 1999).

50. Venezky, Richard L. "Matching Literacy Testing with Social Policy: What Are the Alternatives?" [1994]. Internet address: http://www.nald.ca/fulltext/report4/rep36-40/ rep39-03.htm (last visited January 20, 1999).

51. Taylor, Denny, ed. Many Families, Many Literacies: An International Declaration of Principles. Portsmouth, N.H.: Heinemann Trade, 1997. 